\title{
Blood sulphate concentration in healthy horses after oral application of laxatives containing sulphur
}

\author{
Alice Snyder', Julia Breverl, Gábor Koeller', Jürgen Mattusch², Getu Abraham³ and Gerald Fritz Schusser' \\ 1 Department of Large Animal Medicine, Faculty of Veterinary Medicine, University of Leipzig, Germany \\ 2 Department of Analytical Chemistry, Helmholtz Centre of Environmental Research, Leipzig, Germany \\ 3 Institute of Pharmacology, Pharmacy and Toxicology, Faculty of Veterinary Medicine, University of Leipzig, Germany
}

\begin{abstract}
Summary: Saline laxatives are commonly used to treat colic horses with impaction of the cecum or large colon. The objective of this study was to investigate blood sulphate concentrations in healthy horses before and after orally administered sodium or magnesium sulphate. Six healthy adult fasted horses were used in a randomized study design with four treatment regimes: Trial 1: $1.8 \%$ sodium sulphate $(20 \mathrm{ml} / \mathrm{kg}$ BW); Trial 2: $4.2 \%$ magnesium sulphate $(20 \mathrm{ml} / \mathrm{kg} \mathrm{BW);} \mathrm{Trial} \mathrm{3:} 25 \%$ sodium sulphate $(4 \mathrm{ml} / \mathrm{kg} \mathrm{BW})$; Trial $4: 25 \%$ magnesium sulphate (4 ml/kg BW). Water was used as a control (Trial 5: $20 \mathrm{ml}$ water $/ \mathrm{kg} \mathrm{BW).} \mathrm{Blood} \mathrm{samples} \mathrm{were} \mathrm{taken} \mathrm{at} \mathrm{defined} \mathrm{time} \mathrm{points.} \mathrm{The} \mathrm{minimal} \mathrm{and}$ maximal value of serum sulphate concentration in healthy fasted horses was 0.29 and $0.42 \mathrm{mmol} / \mathrm{l}$. Sulphate concentrations increased moderately, statistically significant $(P<0.05)$ in Trial $1(0.66 \pm 0.12 \mathrm{mmol} / \mathrm{l}$ after $90 \mathrm{~min})$ and Trial $2(0.57 \pm 0.11 \mathrm{mmol} / \mathrm{l}$ after $150 \mathrm{~min})$, and severely $(P \leq 0.001)$ in Trial $3(1.37 \pm 0.26 \mathrm{mmol} / \mathrm{l}$ after $240 \mathrm{~min})$ and Trial $4(1.01 \pm 0.22 \mathrm{mmol} / \mathrm{l}$ after $240 \mathrm{~min})$ compared to pretest values (Trial 1: $0.29 \pm 0.15 \mathrm{mmol} / \mathrm{l}$; Trial 2: $0.32 \pm 0.06 \mathrm{mmol} / \mathrm{l}$; Trial 3: $0.39 \pm 0.06 \mathrm{mmol} / \mathrm{l}$; Trial 4: $0.39 \pm 0.02 \mathrm{mmol} / \mathrm{l})$. There was no increase in the sulphate concentrations in the control group (Trial 5: $0.42 \pm 0.04 \mathrm{mmol} / \mathrm{l}$ ). We conclude that a single dose of orally administered isotonic sodium or magnesium sulphate increases serum sulphate concentrations moderately, whereas hypertonic sodium or magnesium sulphate increases serum sulphate concentrations greatly in normal horses without clinical signs of adverse reactions.
\end{abstract}

Keywords: horse / colic / sodium sulphate / magnesium sulphate / isotonic / hypertonic

\section{Sulfatkonzentration im Blut gesunder Pferde nach oraler Applikation sulfathaltiger Abführmittel}

Sulfathaltige, salinische Laxantien stellen beim Kolikpferd mit Obstipationen des Zäkums oder des großen Kolons einen wesentlichen Teil der konservativen Therapie dar. Ziel unsere Studie war es die Sulfatkonzentration im Blutserum gesunder Pferde vor und nach oraler Applikation von Natrium- oder Magnesiumsulfat zu ermitteln. Sechs gesunde, adulte, nüchterne Pferde wurden in diese randomisierte Studie mit vier Laxantienprotokollen einbezogen: Protokoll 1: 1,8\% Natriumsulfat (20 ml $/ \mathrm{kg} \mathrm{KG);} \mathrm{Protokoll} \mathrm{2:} \mathrm{4,2 \%} \mathrm{Magnesiumsulfat} \mathrm{(20} \mathrm{ml/kg} \mathrm{KG);}$ Protokoll 3: $25 \%$ Natriumsulfat (4 ml/kg KG); Protokoll 4: $25 \%$ Magnesiumsulfat (4 ml/kg KG). Als Kontrolle wurde Wasser appliziert (Protokoll 5: $20 \mathrm{ml} / \mathrm{kg} \mathrm{KG).} \mathrm{Zu} \mathrm{festgelegten} \mathrm{Zeitpunkten} \mathrm{wurden} \mathrm{Serumproben} \mathrm{entnommen.} \mathrm{Die} \mathrm{minimale} \mathrm{und} \mathrm{maximale} \mathrm{Serumsulfatkonzen-}$ tration nüchterner, gesunder Pferde war 0,29 und 0,42 mmol/l. Die Serumsulfatkonzentrationen stiegen in Protokoll 1 (0,66 0,12 mmol// nach $90 \mathrm{~min})$ und Protokoll $2(0,57 \pm 0,11 \mathrm{mmol} / /$ nach $150 \mathrm{~min})$ mäßig aber statistisch signifikant $(P<0.05)$ und in Protokoll 3 $(1,37 \pm 0,26 \mathrm{mmol} / \mathrm{I}$ nach $240 \mathrm{~min})$ und Protokoll $4(1,01 \pm 0,22 \mathrm{mmol} / \mathrm{I}$ nach $240 \mathrm{~min})$ stark $(\mathrm{P} \leq 0.001)$ an im Vergleich zu den Präwerten (Protokoll 1: 0,29 0,15 mmol/l; Protokoll 2: 0,32 0,06 mmol/l; Protokoll 3: 0,39 $\pm 0,06 \mathrm{mmol} / \mathrm{l}$; Protokoll 4: 0,39 \pm 0,02 mmol/l). In der Kontrollgruppe war kein Konzentrationsanstieg zu verzeichnen (Protokoll 5: 0,42 \pm 0,04 mmol/l). Schlussfolgernd erhöht eine einzelne enterale Applikation isotoner Natrium- oder Magnesiumsulfatlösung die Serumsulfatkonzentration mäßig; hypertone Natriumsulfat- oder Magnesiumsulfatlösung erhöhen die Serumsulfatkonzentration gesunder Pferde stark, ohne klinische Symptome hervorzurufen.

Schlüsselwörter: Pferd / Kolik / Natriumsulfat / Magnesiumsulfat / isoton / hyperton

Correspondence: Prof. Dr. med. vet. Dipl. ECEIM G. F. Schusser, Medizinische Tierklinik, Universität Leipzig, An den Tierkliniken 11, 04103 Leipzig, Germany, E-Mail: schusser@vetmed.uni-leipzig.de

Citation: Snyder A., Brever J., Koeller G., Mattusch J., Abraham G., Schusser G. F. (2014) Blood sulphate concentration in healthy horses after oral application of laxatives containing sulphur. Pferdeheilkunde 30, 297-301

\section{Introduction}

"Glauber's salt" (decahydrated sodium sulphate) and "Epsom salt" (heptahydrated magnesium sulphate) are commonly used in equine practice (Lopes et al. 2004). Both substances retain water osmotically inside the gastrointestinal tract to soften the bowel contents and increase its volume (Grevemeyer 1996). The volume increase distends the intestinal wall, facilitates the transport of intestinal content and promotes intestinal motility (Spallek et al. 2013). Sulphates are poorly absorbed from the gastrointestinal tract and act as potent osmotic cathartics (Morris and Levy 1983a). However, magnesium and sodium sulphate may cause electrolyte imbalances (Lopes et al. 2004, Spallek et al. 2011 ).
Inorganic sulphate is an essential electrolyte which is required by all living organisms for proper cell growth and development. The anion is involved in a variety of important biological processes, including biosynthesis and detoxification via sulphation of many endogenous and exogenous compounds (Markovich 2001). Sulphur is incorporated into many essential molecules, including biotin, chondroitin sulphate, cartilage mucopolysaccharides, co-enzyme A, fibrinogen, glutathione, heparin, lipoic acid, mucins, and thiamine (National Research Council 1989, 1998, 2006). Sulphur is an essential dietary component that can be toxic at high concentrations (Hall 2007). All organ tissues have significant sulphur components, with the body being made up of approximately $0.15 \%$ sulphur 
(National Research Council 2006). The recommended daily feed intake of sulphur is $0.15 \%$ in the diet for horses (National Research Council 1989), compared to $0.15-0.2 \%$ in the feed for beef cattle and $0.2-0.25 \%$ in the feed for dairy cattle (National Research Council 1988, 1996). The United States Environmental Protection Agency (USEPA) recommends a maximum water sulphate concentration of $250 \mathrm{mg} / \mathrm{L}$ for human consumption (Burgess et al. 2010). The recommended maximum water sulphate concentration for livestock in Canada is $1000 \mathrm{mg} / \mathrm{L}$ (Carlson and Ensley 2007).

The chemical form must be considered when evaluating the absorption of sulphur. Sulphur has four different naturally occurring atomic masses from 32 to 36 (Rosman and Taylor 1998). It can occur in four different oxidation states: -2 (sulphide), 0 (elementary sulphur), +4 (sulphite), and +6 (sulphate). All valence states, except elemental sulphur, are found in biologic molecules. These inorganic sulphur compounds of feed will be used after absorption in the synthesis of substances containing sulphur, such as chondroitin, heparin and insulin. Inorganic sulphur is important for the gut flora, which produces microbial protein containing sulphur, from which the essential amino acids methionine and cysteine will be available as an organic sulphur source for horses (National Research Council 2006). In this study, blood sulphate concentrations were investigated in healthy fasted horses after a single administration of isotonic or hypertonic solution of sodium or magnesium sulphate. We hypothesized that isotonic solutions do not increase serum sulphate concentrations in contrast to hypertonic solutions.

\section{Materials and Methods}

Horses

Six German adult Warmblood horses (two mares, three geldings and one stallion) from the Department of Large Animal Medicine research unit, Leipzig University, were included in the study. The animals were 6 to 24 years old (average 15 years) with a body weight (BW) of 406 to $680 \mathrm{~kg}$ (average $573 \mathrm{~kg}$ ). They were kept in straw-bedded stalls and received standard hay and grain feed twice daily over a period of four weeks prior to this study and were routinely dewormed for intestinal parasites.

The horses were fasted overnight for a minimum of ten hours with free access to water for the study. In the morning, the horses were physically examined and were weighed for the determination of the laxative dosage and water volumes. Blood samples were collected using a jugular venous catheter (Braunuele MT/G 14, Braun AG, DE) for the analysis of complete blood counts and the evaluation of routine biochemistry using automatic analysers (ADVIA 120, Bayer Diagnostics $\mathrm{GmbH}$, DE; Hitachi 912, Roche Diagnostics GmbH, DE). The values (data not shown) were used to verify that the horses did not have subclinical inflammation or altered metabolism.

\section{Laxatives}

Each of the four formulations of laxatives was administered to each of the six fasted horses by a nasogastric tube alternately in a randomized study design, as reported recently (Spallek et al. 2013): Trial 1: isotonic sodium sulphate solution $(0.36 \mathrm{~g} / \mathrm{kg}$ BW dissolved in $20 \mathrm{ml}$ water $/ \mathrm{kg}$ BW; wasserfreies Natriumsulphat ${ }^{\circledR}$, WDT eG, DE) $(=1.8 \%)$; Trial 2: isotonic magnesium sulphate solution $(0.84 \mathrm{~g} / \mathrm{kg}$ BW dissolved in $20 \mathrm{ml}$ water/kg BW; magnesium sulphate heptahydrate ${ }^{\circledR}$, Sigma-Aldrich Chemie GmbH, DE) (=4.2\%); Trial 3: hypertonic sodium sulphate solution $(1 \mathrm{~g} / \mathrm{kg}$ BW dissolved in $4 \mathrm{ml}$ water $/ \mathrm{kg} \mathrm{BW;} \mathrm{wasserfreies} \mathrm{Natriumsulphat}{ }^{\circledR}$, WDT eG, DE) (=25\%); Trial 4: hypertonic magnesium sulphate solution ${ }^{\circledR}$ $(1 \mathrm{~g} / \mathrm{kg}$ BW dissolved in $4 \mathrm{ml}$ water/ $\mathrm{kg}$ BW; Magnesium sulphate heptahydrate ${ }^{\circledR}$, Sigma-Aldrich Chemie $\left.\mathrm{GmbH}, \mathrm{DE}\right)$ (=25\%). Tap water was used as a control: Trial 5: $20 \mathrm{ml}$ water $/ \mathrm{kg}$ BW. Each horse had a wash-out period of at least one week between each trial.

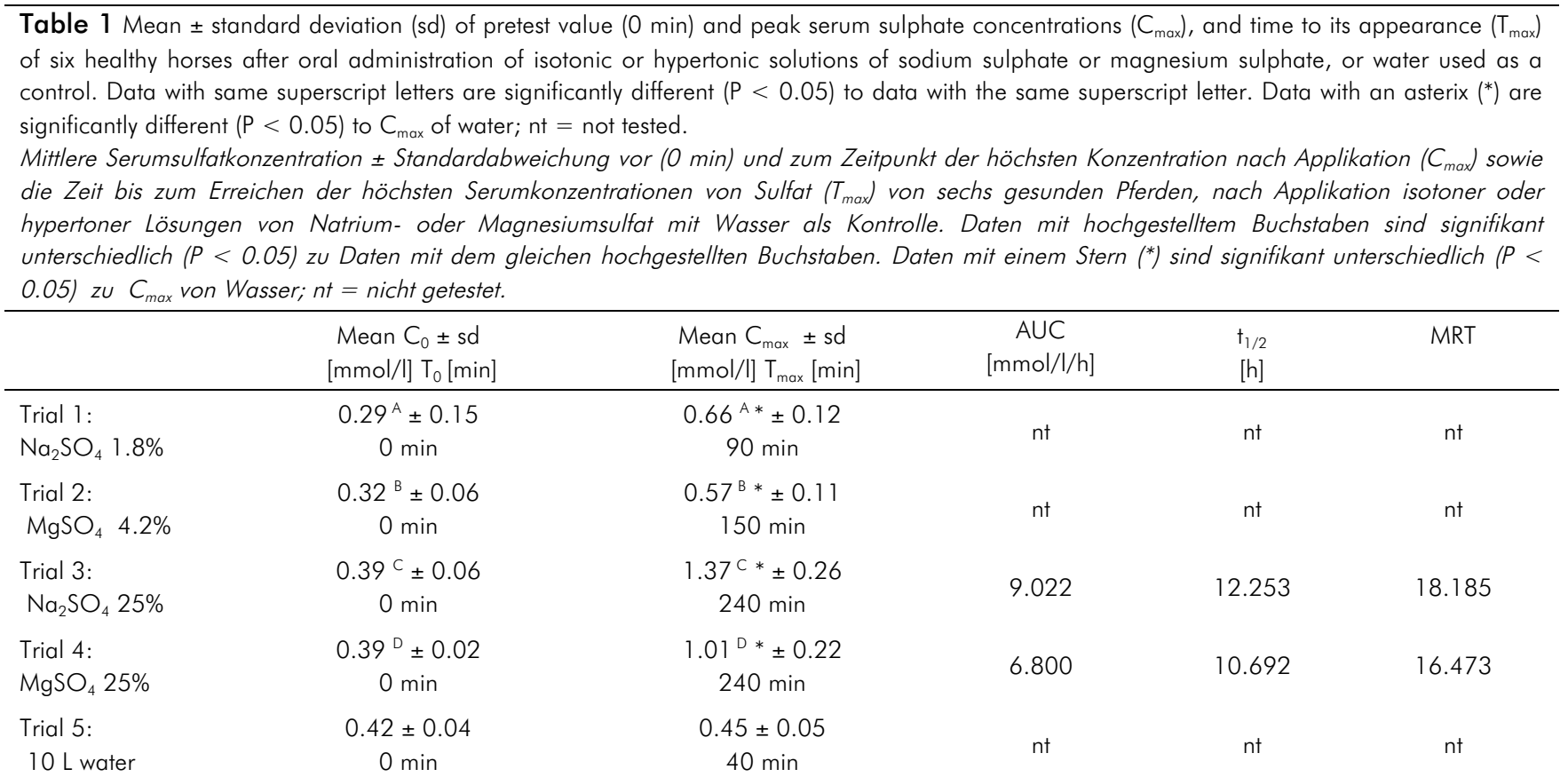




\section{Sampling}

Blood samples were collected in plain tubes before the administration of laxatives (0 $\mathrm{min}$ ) and $10,20,30,40,50,60$, $70,80,90,100,120$, and 150 minutes $(\mathrm{min})$ after the administration of Trials 1, 2 and 5. Blood samples for Trials 3 and 4 were taken at $0,30,60,90,120,180,190,200,210$, 220, 230, 240, 250, 260, 270, 280, 290, 300, 330, 360, 390,420 , and $480 \mathrm{~min}$. Plain tubes were centrifuged (EBA12, Andreas Hettich GmbH\&Ko.KG, DE) at 1,800 × $\mathrm{g}$ for $10 \mathrm{~min}$. Serum was harvested and stored at $-20^{\circ} \mathrm{C}$ until analysis. After the application of solutions, the horses were kept in boxes for a period of five to eight hours without bedding, feed or water. A second physical examination ended the tests; the venous catheter was removed and the horses were taken to bedded boxes with salt blocks and free access to water and feed.

\section{Analysis}

Sulphate concentrations were analysed by ion chromatography (Dx 500, Dionex GmbH, DE) at the Department of Analytical Chemistry of the Helmholtz Centre for Environmental Research in Leipzig, Germany.

\section{Statistics}

Statistical analysis was performed using the Windows software programmes Excel 12.0 and PASW 18.0. The KolmogorovSmirnov test was used to review normal distributions. Sulphate concentrations after administration of each trial were compared to pretest values using the paired t-test. Comparison of serum sulphate concentrations of Trials 1, 2, 3, and 4 (laxatives) with Trial 5 (water control) was performed using the ttest for independent samples. Correlations of $C_{\text {max }}$ between

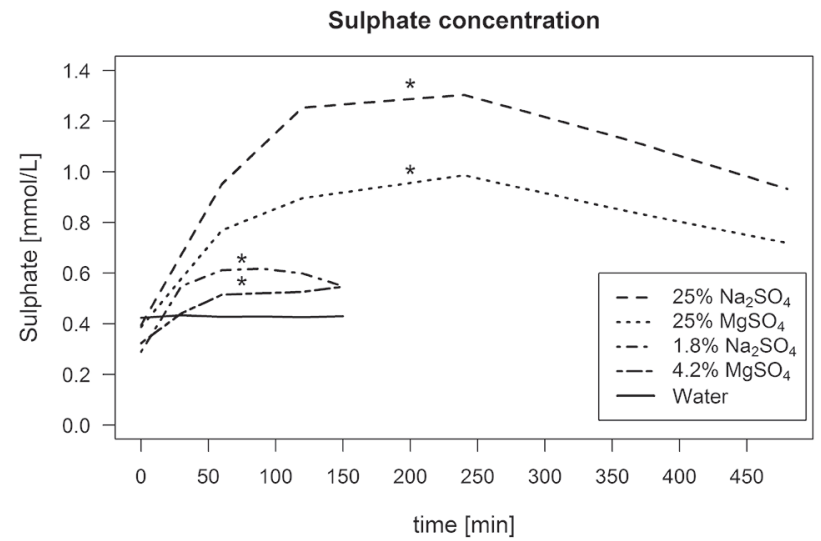

Fig. 1 Mean serum sulphate concentration of six healthy fasted horses after oral administration of $1.8 \%$ sodium sulphate, $4.2 \%$ magnesium sulphate, $25 \%$ sodium sulphate or $25 \%$ magnesium sulphate and water used as control. *Time to reach peak serum concentration $\left(T_{\max }\right)$ significantly different to pre values.

Mittlere Serumsulfatkonzentration sechs gesunder Pferde nach oraler Applikation von 1.8\% Natriumsulfat, 4.2\% Magnesiumsulfat, 25\% Natriumsulfat oder $25 \%$ Magnesiumsulfat und Wasser als Kontrolle. *Zeit bis zum Erreichen der maximalen Serumkonzentration ( $\left.T_{\max }\right)$ signifikant unterschiedlich zu Praewerten. trials were calculated using the Spearman rank correlation coefficient (SRCC). Values of $\mathrm{P}<0.05$ were considered significant.

\section{Results}

All horses remained bright and alert throughout the study. Mean pre and peak serum sulphate concentrations $\left(C_{\max }\right)$ and standard deviation ( $x \pm s d$ ) are shown in Table 1 , as well as median times to reach maximum serum concentrations $\left(T_{\text {max }}\right)$. The concentrations versus time curves of all trials are shown in Figure 1.

Serum sulphate concentrations increased significantly after the administration of saline cathartics in comparison to pretest values. Peak sulphate concentrations were were significantly higher in Trial $1(P=0.006)$, Trial $2(P=0.035)$, Trial $3(P=0.000)$, and Trial $4(P=0.001)$ in comparison to water. A significant positive correlation (SRCC $=0.841$ ) was detected between the $C_{\text {max }}$ of Trial 1 and Trial $2(P=0.036)$. The minimal and maximal value of serum sulphate concentration in healthy fasted horses was 0.29 and $0.42 \mathrm{mmol} / \mathrm{l}$. Results of the electrolyte and water balance have been published recently elsewhere (Spallek et al. 2011).

\section{Discussion}

Impaction of the large colon is a common cause of colic in horses (Hudson et al. 2001, White 1990). The standard treatment used in horses for simple large colon impaction is a combination of laxatives and visceral analgesics (Doran 1993, Lopes et al. 2004). The main finding of this study is the exorbitantly significant increase in blood sulphate concentration after the oral administration of hypertonic solution of sodium sulphate or magnesium sulphate. These findings were less severe with isotonic solutions.

Generally, in all mammalian species, sulphate can be directly obtained from nutrition (Ittyerah 1969, Smith and Mitchell 1974) or formed by the oxidation of the amino acids containing sulphur, cysteine and methionine, in the diet (Krijgsheld et al. 1981, Sabry et al. 1965). All cells require inorganic sulphate for physiological function and it is involved in several activation and detoxification processes of many endogenous (including glycosaminoglycans, cerebrosides, steroids, catecholamines) and exogenous (acetaminophen, isoproterenol, ibuprofen, salicylate, $\alpha$-methyldopa) compounds (Mulder 1981, Mulder and Jakoby 1990). Sulphur is obtained from sulphate, and the former has a hydrophilic property and cannot penetrate the lipid bilayer of the cell membrane; therefore, all cells require a mechanism for sulphate influx and efflux to ensure an optimal supply of sulphate in the organism (Markovich 2001). The intestinal mucosal absorption of sulphate is caused by an active carrier mediated process which is utilized by molybdate (Mason and Cardin 1977). It has been shown in sheep, rats, hamsters, and rabbits that intestinal absorption of sulphate ions is accomplished by active transport (Anast et al. 1965, Bird and Moir 1971). Similarly, the amino acids containing sulphur and other compounds containing sulphur are absorbed via specific transport mechanisms across the intestinal mucosa (National Research Council 2006). 
The plasma concentration of $\mathrm{SO}_{4}^{2-}$ in humans is generally maintained fairly constantly $( \pm 10 \%)$ over a 24 -hour period (Meier and Schmidt-Kessen 1978). However, the plasma $\mathrm{SO}_{4}{ }^{2-}$ level can increase up to two-fold above normal level after oral $\mathrm{SO}_{4}^{2-}$ loading (i.e. high protein diets), whereby excess $\mathrm{SO}_{4}{ }^{2-}$ can quickly be excreted within $12 \mathrm{~h}$. By contrast, the majority of filtered $\mathrm{SO}_{4}{ }^{2-}$ is reabsorbed during fasting (Meier and Schmidt-Kessen 1978, Neiberger 1991). Indeed, plasma sulphate levels have not yet been determined in horses or other large animals.

Since sulphate is not largely bound to plasma proteins and the majority of filtered sulphate is reabsorbed, it has been suggested that sulphate homeostasis in the organism is partly maintained through renal clearance mechanisms (Becker et al. 1960, Berglund 1960). Inorganic sulphate is eliminated from the organism almost entirely by renal excretion without biotransformation. Therefore, analysis of the urinary excretion rate helps to provide bioavailability of orally administered sulphate (Cocchetto and Levy 1981). Cocchetto and Levy (1981) measured $43.5 \pm 12.0 \%$ of $(18.1 \mathrm{~g})$ inorganic sulphate in the 24-hour urine of healthy subjects after oral administration of sodium sulphate. On the contrary, Morris and Levy (1983b) reported a lesser bioavailability of sulphate from magnesium sulphate and recovered $30.5 \pm 17.0 \%$ of the ingested dose $(13.9 \mathrm{~g})$ in the 24 -hour urine of healthy subjects. Unfortunately, urine sulphate concentrations were not investigated in this study.

Oral administration of sodium sulphate in humans leads to an increase in the plasma sulphate level (Cocchetto and Levy 1981). A dose of $9 \mathrm{~g}$ sodium sulphate decahydrate (about $0.12 \mathrm{~g} / \mathrm{kg} \mathrm{BW}$ ) increased the serum concentration of inorganic sulphate significantly (mean $0.51 \pm 0.06 \mathrm{mmol} / \mathrm{l}$ after $2 \mathrm{~h}$ ) in normal subjects compared to a water control (0.41 $\pm 0.04 \mathrm{mmol} / \mathrm{l})$ (Morris and Levy 1983a). To the best of our knowledge, blood sulphate concentrations have not been investigated in horses after the administration of sodium or magnesium sulphate, and reference values for serum sulphate concentrations of horses do not exist in the literature.

In the present study, serum sulphate concentrations increased slightly more after sodium sulphate than after magnesium sulphate administration. These findings match the data of previous studies, where the bioavailability of sulphate from sodium sulphate was higher and more stable in comparison to sulphate from a magnesium sulphate, but there was no statistically significant difference (Cocchetto and Levy 1981, Morris and Levy 1983b). The fact that magnesium sulphate might cause pronounced diarrhoea (Morris and Levy 1983b) while sodium sulphate had much milder effects on bowel function (Cocchetto and Levy 1981) could not be confirmed in horses (Spallek et al. 2011 1). When isotonic solutions of sodium or magnesium sulphate were orally administered in our study, we observed that only a very low amount was recovered in the blood, suggesting that very little of the compound was absorbed and the main part (99\%) would have to be eliminated with the faeces. On the other hand, whenhypertonic solutions of sodium or magnesium sulphate were administered, less than $2 \%$ of sulphate was absorbed. These observations contrast with previous findings that large doses of sodium sulphate (18 $\mathrm{g}$ decahydrate equivalent to $8 \mathrm{~g}$ anhydrous) are well tolerated and will be absorbed to a large extend (Cocchetto and Levy 1981). Morris and Levy (1983b)recommend oral sodium sulphate to replenish systemic sulphate.

Sulphate and magnesium ions are poorly absorbed from the gastrointestinal tract. The capacity of the specialized enteric transport systems can be exceeded especially when administered in large amounts (Anast et al. 1965, Brannan et al. 1976, Stewart et al. 1975). Acute clinical and pathological manifestations from oral sulphur poisoning are similar across species (Gunn et al. 1987, Julian and Harrison 1975, White 1964); often expected clinical signs include abdominal pain, colic, rumen stasis, fetid diarrhoea, dehydration, metabolic acidosis, tachycardia, recumbency, and hydrogen sulphide smell. Irritation, oedema and haemorrhage in the gastrointestinal and respiratory tract might be observed. In addition, renal tubular necrosis can be expected (Hall 2007). Ruminants, especially, seem to be more sensitive to the toxic effects of nutritional sulphur/sulphate due to efficient microbial conversion to bioactive species in the rumen (Block et al. 1951, Hall 2007). Monogastric animals are rather less susceptible to the subacute direct and indirect toxic effects of excessive sulphur intake than ruminants, since the indirect toxic effects of excessive sulphur are related to rumen conversion to sulphide (Hall 2007). Absorbed sulphides can pass the bloodbrain barrier, and absorbed thiomolybdates, the primary toxic sulphur metabolites, can deplete tissue stores of copper, which results in adverse reactions (Hall 2007).

Both dietary and water sources of sulphur/sulphate have similar toxic potential and must be considered in the total daily intake calculations in order to avoid potential risks (Hall 2007). High sulphate intake in horses results in osmotic diarrhoea (Murray 2002). Burgess et al. (2010) reported poor water quality with high salinity and high sulphate concentration (22,500 mg/l water) causing osmotic diarrhoea, severe dehydration and the death of 5 out of 19 affected horses. Survivors showed severe neurologic signs, consistent with cerebral and brainstem dysfunction, attributed to acute hyponatraemia. Up to now, sulphate concentrations have only been analysed in water samples, but not in the blood of affected horses. Horses, for example, have an average of $50 \mathrm{ml} / \mathrm{kg} \mathrm{BW} / \mathrm{d}$ water intake. Based on this, a horse with a $500 \mathrm{~kg} \mathrm{BW}$ would drink 25I of water per day containing $562,500 \mathrm{mg}$ sulphate. In comparison to our study, an isotonic (180 g/10 I water) or hypertonic (500 g/2 I water) solution of sodium sulphate only contains $121,632 \mathrm{mg}$ or $338,016 \mathrm{mg}$ sulphate, respectively. However, the isotonic (420 g/ 10 I water) or the hypertonic ( $500 \mathrm{~g} / 2$ I water) solution of magnesium sulphate has a higher concentration of sulphate $(335,136$ vs. $398,994 \mathrm{mg}$, respectively). All these amounts of sulphate were less than the concentration of sulphate found by Burgess et al. (2010) in the drinking water of poisoned horses. The low absorption from the gut and the fast renal excretion of sulphate play an important part in contributing to the balance between the intra- and extracellular fluid.

Plants can accumulate high sulphur concentrations (Hall 2007). Clinical signs of chronic sulphate toxicity in horses include diarrhoea, colic, ataxia, malaise, and, rarely, convulsions (Lorgue et al. 1996). In addition, increase in soil sulphur inhibits the plant uptake of selenium, thereby increasing the potential for inducing selenium deficiency in herbivores 
(Newman and Schreiber 1985). Sulphate-induced selenium deficiency can cause poor growth, weakness, poor immune function, poor reproductive function, damage to the cardiac or skeletal muscle, and death (Hall 2007). None of the aforementioned symptoms were seen in the horses in the present study, and serum sulphate concentrations before administration (time 0) were similar in each trial.

\section{Conclusion and Clinical Relevance}

Depending on the concentration, a conspicuous part of sulphate is absorbed from orally administered saline sulphate containing laxatives, causing increased serum sulphate concentrations. Repeated application of isotonic sodium or magnesium sulphate did not cause clinical signs of hypersulphataemia in healthy adult horses. Thus, it can be advised that clinicians can use these formulations for the treatment of primary impaction in large colon or cecum of equine patients.

\section{Animal welfare statement}

The trials were approved by the local Commission of Animal Welfare (AZ 24-9168.21 A 8/06).

\section{References}

Anast C., Kennedy R., Volk G., Adamson L. (1965) In vitro studies of sulphate transport by the small intestine of the rat, rabbit, and hamster. J. Lab. Clin. Med. 65, 903-911

Becker E. L., Heinemann H. O., Igaraski K., Hodler J. E., Gershberg H. (1960) Renal mechanisms for the excretion of inorganic sulphate in man. J. Clin. Invest. 39, 1909-1913

Berglund F. (1960) Transport of inorganic sulphate by the renal tubules. Acta Physiol. Scand. 49, 1-37

Bird P. R., Moir R. J. (1971) Sulphur metabolism and excretion studies in ruminants. I. The absorption of sulphate in sheep after intraruminal or intraduodenal infusions of sodium sulphate. Aust. J. Biol. Sci. 24, 1319-1328

Block R. J., Stekol J. A., Loosli J. K. (1951) Synthesis of sulphur amino acids from inorganic sulphate by ruminants. II. Synthesis of cystine and methionine from sodium sulphate by the goat and by the microorganisms of the rumen of the ewe. Arch. Biochem. Biophys. 33, 353-363

Brannan P. G., Vergne-Marini P., Pak C. Y., Hull A. R., Fordtran J. S. (1976) Magnesium absorption in the human small intestine. Results in normal subjects, patients with chronic renal disease, and patients with absorptive hypercalciuria. J. Clin. Invest. 57, 1412-1418

Burgess B. A., Lohmann K. L., Blakley B. R. (2010) Excessive sulphate and poor water quality as a cause of sudden deaths and an outbreak of diarrhea in horses. Can. Vet. J. 51, 277-282

Carlson M. P., Ensley S. (2007) Water quality and contaminants: Veterinary Toxicology - basic and clinical principles. Academic Press/Elsevier, New York, NY USA, p. 1045-1059

Cocchetto D. M., Levy G. (1981) Absorption of orally administered sodium sulphate in humans. J. Pharm. Sci. 70(3), 331333

Doran R. (1993) Field management of simple intestinal-obstruction in horses. Compend. Contin. Educ. Vet.15, 463-471

Grevemeyer B. (1996) Zur Obstipatio coli ascendentis des Pferdes/ Equine colon impaction equine colon impaction. Pferdeheilkunde $12,765-772$

Gunn M. F., Baird J. D., Wilkie J. S. (1987) Accidental sulfur poisoning in a group of holstein heifers. Can. Vet. J. 28, 188-192

Hall J. O. (2007) Molybdenium. In: Veterinary Toxicology - basic and clinical principles. Ed. R. C. Gupta, Academic Press/ Elsevier, New York, NY USA, p. 449-453
Hudson J. M., Cohen N. D., Gibbs P. G., Thompson J. A. (2001) Feeding practices associated with colic in horses. J. Am. Vet. Med. Assoc. 219, 1419-1425

Ittyerah T. R. (1969) Urinary excretion of sulphate in Kwashiorkor. Clin. Chim. Acta 25, 365-369

Julian R. J., Harrison K. B. (1975) Sulphur poisoning in cattle. Can. Vet. J. 16, 28-29

Krijgsheld K. R., Scholtens E., Mulder G. J. (1981) An evaluation of methods to decrease the availability of inorganic sulphate for sulphate conjugation in the rat in vivo. Biochem. Pharmacol. 30, 1973-1979

Lopes M. A., White N. A. 2nd, Donaldson L., Crisman M. V., Ward D. L. (2004) Effects of enteral and intravenous fluid therapy, magnesium sulphate, and sodium sulphate on colonic contents and feces in horses. Am. J. Vet. Res. 65, 695-704

Lorgue G., Lechenet J., Rivière A. (1996) Sulphur. In: Clinical Veterinary Toxicology. Ed. M. J. Chapman, Blackwell Sci., Oxford, UK, p. 176-177

Markovich D. (2001) Physiological roles and regulation of mammalian sulphate transporters. Physiol. Rev. 81, 1499-1533

Mason J., Cardin C. J. (1977) The competition of molybdate and sulphate ions for a transport system in the ovine small intestine. Res. Vet. Sci. 22, 313-315

Meier M. S., Schmidt-Kessen W. (1978) Studies on the metabolism of inorganic sulphate. Munch. Med. Wochenschr. 120, 357-362

Morris M. E., Levy G. (1983a) Serum concentration and renal excretion by normal adults of inorganic sulphate after acetaminophen, ascorbic acid, or sodium sulphate. Clin. Pharmacol. Ther. 33, 529-536

Morris M. E., Levy G. (1983b) Absorption of sulphate from orally administered magnesium sulphate in man. J. Toxicol. Clin. Toxicol. 20, 107-114

Mulder G. J. (1981) Sulphation of Drugs and Related Compounds. Boca Raton, CRC Press, Florida, USA

Mulder G. J., Jakoby W. B. (1990) Sulphation. In: Conjugation Reactions in Drug Metabolism: An Integrated Approach: Substrates, Co-substrates, Enzymes and Their Interactions In Vivo and In Vitro. Ed. G. J. Mulder, Taylor and Francis, London, p. 107-161

National Research Council (2006) Molybdenium. In: Mineral Tolerance of Animals, 2 nd edition. National Academies Press; Washington DC, USA, p. 262-275

National Research Council (1989) Nutrient Requirements of Horses, 6th edition. National Academies Press; Washington DC, USA, p. 28-29

National Research Council (1998) Nutrient Requirements of Swine, 10th edition. National Academies Press; Washington DC, USA, p. 60-61

Neiberger R. E. (1991) Adaptation of renal sulphate transport in response to dietary sulphate intake in guinea pigs. Child Nephrol. Urol. 11, 61-64

Rosman K. J. R., Taylor P. D. P. (1998) Isotopic compositions of the elements 1997. Pure Appl. Chem. 70, 217-235

Sabry Z. I., Shadarevian S. B., Cowan J. W., Campbell J. A. (1965) Relationship of dietary intake of sulphur amino-acids to urinary excretion of inorganic sulphate in man. Nature 206, 931-933

Smith I., Mitchell P. D. (1974) The effect of oral inorganic sulphate on the metabolism of 4-hydroxyphenethylamine (tyramine) in man: tyramine $\mathrm{O}$-sulphate measurement in human urine. Biochem. J. 142, 189-191

Spallek A., Brever J., Recknage/ S., Koeller G., Schusser G. F. (2011) Influence of laxatives on electrolyte and water balance in normal horses. Pferdeheilkunde 27, 487-494

Spallek A., Recknagel S., Brever J., Koeller G., Schusser G. F. (2013) Influence of laxatives on gastric emptying in healthy Warmblood horses evaluated with the D-xylose adsorption test. Berl. Münch. Tierarztl. Wochenschr. 126, 10-15

Stewart J. J., Gaginella T. S., Olsen W. A., Bass P. (1975) Inhibitory actions of laxatives on motility and water and electrolyte transport in the gastrointestinal tract. J. Pharmacol. Exp. Ther. 192, 458-467

White J. B. (1964) Sulfur poisoning in ewes. Vet. Rec. 76, 278-279

White N. A. (1990) The Equine Acute Abdomen. Lea and Febiger, Philadelphia, PA, USA 


\section{Einleitung}

"Glaubersalz" (Natriumsulfatdekahydrat) und "Bittersalz" (Magnesiumsulfatheptahydrat) werden in der Pferdepraxis häufig verwendet (Lopes et al. 2004). Beide Substanzen halten im Gastrointestinaltrakt osmotisch Wasser zurück, wodurch der Darminhalt aufgeweicht und sein Volumen erhöht wird (Grevemeyer 1996). Die Volumenzunahme erleichtert die Ingestapassage, dehnt die Darmwand und fördert die Darmmotilität (Spallek et al. 2013). Sulfate werden nur schlecht vom Magendarmtrakt resorbiert und wirken somit als potente osmotische Abführmittel (Morris und Levy 1983a). Magnesium- und Natriumsulfat können jedoch Elektrolytimbalancen hervorrufen (Lopes et al. 2004, Spallek et al. 2011 ).

Anorganisches Sulfat ist ein essentielles Elektrolyt, dass von allen Lebewesen für Zellwachstum und -entwicklung benötigt wird. Das Anion ist bei einer Vielzahl wesentlicher biologischer Vorgänge beteiligt, wie Biosynthese und Entgiftung endogener und exogener Verbindungen durch Sulfatierung (Markovich 2001). Schwefel (Sulfur) ist in zahlreichen essentiellen Molekülen enthalten, einschließlich Biotin, Chondroitinsulfat, Mucopolysaccharide des Knorpels, Co-Enzym A, Fibrinogen, Glutathion, Heparin, Liponsäure, Muzine und Thiamin (National Research Council 1989, 1998, 2006). Schwefel ist ein essentieller Nahrungsbestandteil, der in hohen Konzentrationen toxisch sein kann (Hall 2007). Alle organischen Gewebe haben einen beträchtlichen Schwefelanteil; so besteht der Körper zu etwa 0,15\% aus Schwefel (National Research Council 2006). Die empfohlene Tageszufuhr von Schwefel beträgt für Pferde 0,15\% (National Research Council 1989), für Mastrinder 0,15-0,2\% und für Milchrinder 0,2-0,25\% der Ration (National Research Council 1988, 1996). Die Behörde der Vereinigten Staaten für Umweltschutz (United States Environmental Protection Agency; USEPA) empfiehlt für Verbraucher eine maximale Wassersulfatkonzentration von $250 \mathrm{mg} / \mathrm{L}$ (Burgess et al. 2010). Die empfohlene maximale Wassersulfatkonzentration für Nutztiere beträgt in Canada $1000 \mathrm{mg} / \mathrm{L}$ (Carlson und Ensley 2007).

Um die Resorption von Schwefel zu bewerten, muss die chemische Form berücksichtigt werden. Schwefel hat vier natürlich vorkommenden Atommassen, von 32 bis 36 (Rosman und Taylor 1998). Es kann in vier Oxidationsstadien vorkommen: -2 (Sulfid), 0 (elementarer Schwefel), +4 (Sulfit), und +6 (Sulfat). Alle Wertigkeitsstadien, abgesehen von elementarem Schwefel, kommen in biologischen Molekülen vor. Nach Resorption der im Futter enthaltenen anorganischen Schwefelverbindungen, werden diese zur Synthese schwefelhaltiger Substanzen verwendet, wie Chondroitin, Heparin und Insulin. Anorganischer Schwefel ist zudem wichtig für die Darmflora, die mikrobielles, schwefelhaltiges Protein herstellt, als Grundlage der essentiellen Aminosäuren Methionin und Cystein, die als organische Schwefelquelle für Pferde nutzbar sind (National Research Council 2006). In dieser Studie wurden Sulfatkonzentrationen im Blut gesunder, nüchterner Pferde untersucht, nach Gabe einer einzelnen isotonen oder hypertonen Lösung von Natrium- oder Magnesiumsulfat. Wir gingen davon aus, dass isotone Lösungen die Serumsulfatkonzentration nicht erhöhen, im Unterschied zu hypertonen Lösungen.

\section{Material und Methoden}

Pferde

Sechs adulte deutsche Warmblutpferde (zwei Stuten, drei Wallache und ein Hengst) der Medizinischen Tierklinik der Universität Leipzig wurde in die Studie einbezogen. Die Tiere waren 6 bis 24 Jahre alt (Mittelwert 15 Jahre) mit einem Körpergewicht (KG) von 406 bis $680 \mathrm{~kg}$ (Mittelwert $573 \mathrm{~kg}$ ). Sie wurden in Boxen mit Stroheinstreu gehalten und erhielten über einen Zeitraum von vier Wochen vor Beginn der Studie Heu sowie zweimal täglich Kraftfutter. Sie wurden regelmäßig gegen Magen-Darm-Parasiten behandelt.

Für die Studie wurden die Pferde über Nacht für mindestens 10 Stunden nüchtern gestellt mit freiem Zugang zu Wasser. Am Morgen wurden sie allgemein untersucht und für die genaue Bestimmung der Dosierung der Laxativa und des zugegebenen Wassers gewogen. Blutproben wurden über einen Jugularvenenkatheter (Braunüle MT/G 14, Braun AG, Deutschland) entnommen. Es wurden ein Blutbild und die klinische Chemie mit automatischen Analysegeräten bestimmt (ADVIA 120, Bayer Diagnostics GmbH; Hitachi 912, Roche Diagnostics $\mathrm{GmbH}$, Deutschland). Die Blutuntersuchungsergebnisse (nicht aufgeführt) wurden genutzt, um sicherzustellen, dass die Pferde keine subklinische Entzündung oder Stoffwechselveränderungen hatten.

\section{Laxantien}

Im Rahmen eines randomisierten Studiendesigns wurde jedes der vier Laxantien alternierend jedem der sechs gefasteten Pferde über eine Nasenschlundsonde verabreicht, wie kürzlich beschrieben (Spallek et al. 2013): Versuch 1: Isotone Natriumsulfatlösung $(0,36 \mathrm{~g} / \mathrm{kgKG}$ gelöst in $20 \mathrm{ml} \mathrm{Wasser} / \mathrm{kg}$ KG; wasserfreies Natriumsulphat ${ }^{\circledR}$, WDT eG, DE) (=1,8\%); Versuch 2: isotone Magnesiumsulfatlösung $(0,84 \mathrm{~g} / \mathrm{kgKG}$ gelöst in $20 \mathrm{ml}$ Wasser/kgKG; Magnesiumsulfatheptahydrat ${ }^{\circledR}$, Sigma-Aldrich Chemie GmbH, Deutschland) (=4,2\%); Versuch 3: hypertone Natriumsulfatlösung $(1 \mathrm{~g} / \mathrm{kgKG}$ gelöst in $4 \mathrm{ml}$ Wasser/kgKG; wasserfreies Natriumsulphat ${ }^{\circledR}$, WDT eG) (=25\%); Versuch 4: hypertone Magnesiumsulfatlösung $(\mathrm{lg} / \mathrm{kg} \mathrm{KG}$ gelöst in $4 \mathrm{ml}$ Wasser/kgKG; Magnesiumsulfatheptahydrat $^{\circledR}$, Sigma-Aldrich Chemie GmbH) (=25\%). Leitungswasser wurde als Kontrolle eingesetzt: Versuch 5: $20 \mathrm{ml}$ Wasser/kgKG. Jedes Pferd hatte eine Auswaschzeit von mindestens einer Woche zwischen den einzelnen Durchgängen.

\section{Probenentnahme}

Die Blutproben wurden vor Gabe der Laxantien (0 min) in Serumröhrchen gesammelt sowie 10, 20, 30, 40, 50, 60, 70, 80, 90, 100, 120, und 150 Minuten (min) nach Gabe der Versuche 1, 2 und 5. Blutproben für die Durchgänge 3 und 4 wurden genommen nach $0,30,60,90,120,180$, $190,200,210,220,230,240,250,260,270,280,290$, $300,330,360,390,420$, und $480 \mathrm{~min}$. Die Serumröhrchen wurden zentrifugiert (EBA12, Andreas Hettich GmbH\&Ko.KG, Deutschland) bei 1800 x g für 10 min. Das Serum wurde ab pipettiert und bis zur Analyse bei $-20^{\circ} \mathrm{C}$ aufbewahrt. Nach Verabreichung der jeweiligen Lösung, wurden die Pferde für einen Zeitraum von fünf bis acht Stunden in einer Box ohne Einstreu, Futter oder Wasser gehalten. Eine zweite allgemeine Untersuchung beendete den Versuch. Der Venenkatheter wur- 
de entfernt und die Pferde wurden in Boxen mit Einstreu, Salzleckstein und freiem Wasserzugang verbracht.

Analyse

Die Bestimmung der Sulfatkonzentrationen erfolgte mittels lonenchromatographie (Dx 500, Dionex GmbH, Deutschland) im Institut für Analytische Chemie des Helmholtz-Zentrums für Umweltforschung in Leipzig, Deutschland.

\section{Statistik}

Die statistische Auswertung erfolgte mit Hilfe der Windows Softwareprogramme Excel 12.0 und PASW 18.0. Der Kolmogorov-Smirnov-Test wurde zur Überprüfung der Normalverteilung angewandt. Die Sulfatkonzentrationen nach Gabe der jeweiligen Lösung wurden mit Hilfe des gepaarten t-Tests mit den Ausgangswerten verglichen. Der Vergleich der Serumsulfatkonzentrationen der Versuche 1, 2, 3 und 4 (Laxantien) mit Versuch 5 (Wasserkontrolle) wurde mittels des t-Tests für unabhängige Proben durchgeführt. Die Bestimmung der Korrelation von Cmax zwischen den einzelnen Versuchen erfolgte mit dem Spearman Rangkorrelationskoeffizienten (SRCC). Werte von $p<0,05$ wurden als statistisch signifikant angesehen.

\section{Ergebnisse}

Alle Pferde waren während der gesamten Studie ruhig und aufmerksam. Die Mittelwerte vor (0 min) und zum Zeitpunkt der maximalen Sulfatkonzentrationen $\left(C_{\max }\right)$ sowie die Standardabweichung $(x \pm s d)$ werden in Tabelle 1 dargestellt, ebenso wie die mediane Zeit bis zum Erreichen der maximalen Serumkonzentration $\left(T_{\text {max }}\right)$. Die Konzentration versus ZeitKurve aller Versuche ist in Abbildung 1 dargestellt.

Die Serumsulfatkonzentrationen stiegen im Vergleich zu den Ausgangswerten nach Gabe der salinischen Abführmittel signifikant an. Die maximalen Sulfatkonzentrationen waren in Versuch $1(p=0,006)$, Versuch $2(p=0,035)$, Versuch 3 $(p=0,000)$, und Versuch $4(p=0,001)$ signifikant höher im Vergleich zu Wasser. Eine signifikante positive Korrelation (SRCC $=0,841$ ) wurde zwischen der $C_{\max }$ der Versuche 1 und $2(p=0,036)$ ermittelt. Die minimale und maximale Serumsulfatkonzentration gesunder, nüchterner Pferde liegt bei 0,29 und 0,42 mmol/I. Die Ergebnisse des Elektrolyt- und Wasserhaushaltes wurden bereits veröffentlicht (Spallek et al. 2011).

\section{Diskussion}

Die Obstipation des großen Kolons ist beim Pferd eine häufige Kolikursache (Hudson et al. 2001, White 1990). Die Routinebehandlung von Pferden mit primärer Kolonobstipation umfasst eine Kombination von Laxantien und viszeralen Analgetika (Doran 1993, Lopes et al. 2004). Die wesentliche Erkenntnis dieser Studie ist der exorbitante Anstieg der Blutsulfatkonzentration nach oraler Gabe hypertoner Natriumoder Magnesiumsulfatlösung. Dieser Anstieg war weniger stark ausgeprägt nach Gabe isotoner Lösungen.

Im Allgemeinen kann Sulfat bei allen Säugetierspezies direkt über die Nahrung aufgenommen werden (Ittyerah 1969,
Smith und Mitchell 1974), oder durch Oxidation der in der Nahrung enthaltenen schwefelhaltigen Aminosäuren Cystein und Methionin hergestellt werden (Krijgsheld et al. 1981, Sabry et al. 1965). Anorganisches Sulfat wird für physiologische Stoffwechselvorgänge von allen Zellen benötigt und ist an vielen Aktivierungs- und Entgiftungsprozessen zahlreicher endogener (einschließlich Glycosaminoglykane, Zerebroside, Steroide, Katecholamine) und exogener Verbindungen (Acetaminophen, Isoproterenol, Ibuprofen, Salizylat, -Methyldopa) beteiligt (Mulder 1981, Mulder und Jakoby 1990). Schwefel entsteht aus Sulfat und hat hydrophile Eigenschaften, so dass es die Lipiddoppelschicht von Zellmembranen nicht penetrieren kann. Um eine optimale Sulfatversorgung im Organismus zu gewährleisten, benötigen alle Zellen einen Mechanismus für den Sulfatein- und Ausstrom (Markovich 2001). Die Sulfatresorption der Darmschleimhaut geschieht über einen aktiven Carrier, der auch von Molybdat genutz† wird (Mason und Cardin 1977). Bei Schafen, Ratten und Hamstern wurde gezeigt, dass die intestinale Resorption des Sulfations über einen aktiven Transportweg erfolgt (Anast et al. 1965, Bird und Moir 1971). Ebenso werden schwefelhaltige Aminosäuren und andere schwefelhaltige Verbindungen über spezifische Transportmechanismen der Darmschleimhaut aufgenommen (National Research Council 2006).

Beim Menschen wird die Plasmasulfatkonzentration innerhalb von 24 Stunden recht konstant gehalten ( $\pm 10 \%$ ) (Meier und Schmidt-Kessen 1978). Nach oraler Sulfataufnahme (wie proteinreiche Nahrung), kann die Plasmasulfatkonzentration bis auf das Zweifache der Normalwerte ansteigen, gefolgt von schneller Ausscheidung des überschüssigen Sulfates binnen 12 Stunden. Im Gegensatz dazu wird der Großteil des gefilterten Sulfates während des Fastens rückresorbiert (Meier und Schmidt-Kessen 1978, Neiberger 1991). Beim Pferd oder bei anderen Großtieren wurden Plasmasulfatwerte allerdings bisher noch nicht untersucht.

Da Sulfat weitestgehend nicht an Plasmaproteine gebunden ist und der Großteil des gefilterten Sulfates rückresorbiert wird, wurde angenommen, dass die Sulfathomöostase des Körpers teilweise durch renale Ausscheidungsmechanismen aufrechterhalten wird (Becker et al. 1960, Berglund 1960). Anorganisches Sulfat wird fast ausschließlich durch renale Exkretion vom Organismus eliminiert, ohne Biotransformation. Daher ist die Untersuchung der renalen Ausscheidungsrate zur Bestimmung der Bioverfügbarkeit oral verabreichten Sulfates hilfreich (Cocchetto und Levy 1981). Cocchetto und Levy (1981) konnten 43.5 $\pm 12.0 \%$ des anorganischen Sulfates $(18.1 \mathrm{~g})$ nach oraler Natriumsulfatgabe im 24-Stundenurin gesunder Versuchspersonen nachweisen. Im Gegensatz dazu ermittelten Morris und Levy (1983b) eine geringere Sulfatbioverfügbarkeit von Magnesiumsulfat, da lediglich $30.5 \pm 17.0 \%$ der aufgenommenen Dosis $(13.9 \mathrm{~g}) \mathrm{im}$ 24-Stundenurin gesunder Versuchspersonen nachgewiesen werden konnte. Leider wurden in der vorliegenden Studie keine Sulfatkonzentrationen im Urin der Pferde bestimmt.

Orale Gabe von Natriumsulfat führt bei Menschen zum Anstieg der Plasmasulfatkonzentration (Cocchetto und Levy 1981). Eine Dosis von $9 \mathrm{~g}$ Natriumsulfatdecahydrat (etwa 0,12 g/ kgKG) erhöhte die Serumkonzentration von anorganischem Sulfat bei gesunden Versuchspersonen signifikant (Mittelwert 0,51 $\pm 0,06 \mathrm{mmol} / \mathrm{l}$ nach $2 \mathrm{~h}$ ) im Vergleich zur 
Wasserkontrolle $(0,41 \pm 0,04 \mathrm{mmol} / \mathrm{l})$ (Morris und Levy 1983a). Gemäß unserem Wissen wurden Blutsulfatkonzentrationen nach Gabe von Natrium- oder Magnesiumsulfat beim Pferd noch nicht untersucht. Auch Referenzwerte für Serumsulfatkonzentrationen existieren in der Literatur nicht.

In der vorliegenden Studie stiegen die Serumsulfatkonzentrationen nach Applikation von Natriumsulfat etwas mehr an als nach Magnesiumsulfat. Diese Feststellung passt zu den Ergebnissen früherer Studien, bei denen die Bioverfügbarkeit von Sulfat bei Natriumsulfat höher und langanhaltender war als bei Magnesiumsulfat, wenn auch nicht statistisch signifikant (Cocchetto und Levy 1981, Morris und Levy 1983b). Die Tatsache, dass Magnesiumsulfat ausgeprägte Diarrhoe auslösen kann (Morris und Levy 1983b), während Natriumsulfat mildere Wirkung auf die Darmfunktion hat (Cocchetto und Levy 1981), konnte dies bei Pferden nicht nachgewiesen werden (Spallek et al. 2011). In dieser Studie stellten wir nach oraler Gabe isotoner Natrium- oder Magnesiumsulfatlösung fest, dass nur ein sehr geringer Teil im Blut wiedergefunden wurde, was darauf hindeutet, dass nur ein sehr geringer Teil resorbiert und der Großteil der Substanz (99\%) mit den Fäzes ausgeschieden wurde. Wurden hypertone Lösungen von Natrium- oder Magnesiumsulfat verabreicht, wurden weniger als $2 \%$ des Sulfates resorbiert. Diese Feststellung steht im Gegensatz zu früheren Untersuchungen, bei denen große Mengen Natriumsulfat (18g Dekahydrat entsprechen $8 \mathrm{~g}$ Anhydrit) gut toleriert und zu einem Großteil resorbiert wurden (Cocchetto und Levy 1981). Morris und Levy (1983b) empfehlen orales Natriumsulfat zum Auffüllen des systemischen Sulfates.

Sulfat- und Magnesiumionen werden vom Magendarmtrakt schlecht aufgenommen. Werden große Mengen verabreicht, kann die Kapazität spezifischer, enteraler Transportsysteme überschritten werden (Anast et al. 1965, Brannan et al. 1976, Stewart et al. 1975). Akute klinische und pathologische Ausprägungen oraler Sulfatvergiftung sind speziesübergreifend ähnlich (Gunn et al. 1987, Julian und Harrison 1975, White 1964). Häufig zu erwartende klinische Symptome umfassen Bauchschmerzen, Kolik, Pansenstase, übelriechende Diarrhö, Dehydratation, metabolische Azidose, Tachykardie, Festliegen und Geruch nach Schwefelwasserstoff. Oftmals treten Ödeme und Blutungen im Gastrointestinal- und Respirationstrakt auf. Auch renale tubuläre Nekrosen sind zu erwarten (Hall 2007). Wiederkäuer scheinen für Vergiftungen durch alimentären Schwefel oder Sulfat besonders empfindlich zu sein, weil durch effiziente, mikrobielle Umwandlungen im Pansen bioaktive Schwefelprodukte entstehen (Block et al. 1951, Hall 2007). Monogastrier sind im Gegensatz zu Wiederkäuern weniger anfällig für subakute direkte und indirekte toxische Wirkungen übermäßiger Schwefelaufnahme, da die indirekten toxischen Wirkungen der übermäßigen Schwefelaufnahme infolge ruminöser Umwandlung zu Sulfid entstehen (Hall 2007). Resorbiertes Sulfit passiert die Bluthirnschranke; resorbiertes Thiomolybdat, das erste toxische Schwefelmetabolit, kann die Gewebespeicher von Kupfer vermindern, wodurch weitere Nebenwirkungen entstehen (Hall 2007).

Nahrungs- bzw. Futtermittelquellen von Schwefel/Sulfat haben ein ebenso toxisches Potential wie Trinkwasser und müssen bei der Berechnung der täglichen Aufnahme gleich- ermaßen berücksichtigt werden, um potentielle Gefahren zu vermeiden (Hall 2007). Eine hohe Sulfataufnahme verursacht beim Pferd osmotische Diarrhö (Murray 2002). Burgess et al. (2010) berichteten von schlechter Wasserqualität mit hohem Salzgehalt und hoher Sulfatkonzentration (22,500 mg/l Wasser), als Ursache osmotischer Diarrhö und schwerwiegender Dehydratation bei 19 Pferden, von denen 5 Tiere starben. Überlebende Pferde zeigten neurologische Zeichen in Form von Zerebralen- und Hirnstammdysfunktionen, die einer akuten Hyponatriämie geschuldet waren. Leider wurden die Sulfatkonzentrationen lediglich in Wasserproben, aber nicht im Blut der betroffenen Pferde untersucht. Pferde nehmen durchschnittlich $50 \mathrm{ml}$ Wassser/kg Körpermasse/Tag auf. Demzufolge würde ein $500 \mathrm{~kg}$ schweres Pferd täglich 25 Liter Wasser mit 562,500 mg Sulfat aufnehmen, berechnet nach der vorhin beschrieben Sulfatkonzentration im Wasser. Im Vergleich enthält isotone $(180 \mathrm{~g} / 101$ Wasser) oder hypertone $(500 \mathrm{~g} / 2$ I Wasser) Lösung von Natriumsulfat dieser Studie nur 121,632 mg bzw. 338,016 mg Sulfat. Isotone (420 g/10l Wasser) oder hypertone (500 g/2 I Wasser) Lösung von Magnesiumsulfat hat jedoch eine höhere Sulfatkonzentration (335,136 bzw. 398,994 $\mathrm{mg}$ ). All diese Sulfatmengen liegen unterhalb der von Burgess et al. (2010) gemessenen, toxischen Sulfatkonzentration im Trinkwasser vergifteter Pferde, die das hoch sulfathältige Trinkwasser über längere Zeit täglich aufnahmen. Die geringe intestinal Resorption und die schnelle renale Ausscheidung von Sulfat spielen beim Ausgleich zwischen intraund extrazellulärer Flüssigkeit eine wesentliche Rolle.

Pflanzen speichern große Sulfatmengen (Hall 2007). Klinische Zeichen chronischer Sulfatvergiftung umfassen beim Pferd Diarrhö, Kolik, Ataxie, Unwohlsein und selten Krämpfe (Lorgue et al. 1996). Zudem hemmt ein erhöhter Bodensulfatgehalt die Selenaufnahme von Pflanzen, wodurch die Möglichkeit eines Selenmangels bei Herbivoren steigt (Newman und Schreiber 1985). Sulfatbedingter Selenmangel kann zu schlechtem Wachstum, Schwäche, mangelhafter Immunabwehr, niedriger Fruchtbarkeit, Herz- und Skelettmuskelschäden sowie zum Tod führen (Hall 2007). In der vorliegenden Studie wurde keines dieser Symptome beobachtet und die Serumsulfatkonzentrationen waren vor Administration der Lösungen (Zeit 0) in jedem Versuch ähnlich und unterschieden sich nicht von der Kontrollgruppe.

\section{Schlussfolgerung und klinische Relevanz}

Abhängig von der Konzentration, wird ein Teil des Sulfates nach oraler Gabe salinischer, sulfathaltiger Abführmittel resorbiert, wodurch die Serumsulfatkonzentration ansteigt. In einwöchigem Abstand wiederholte Gaben isotonen Natriumoder Magnesiumsulfates riefen bei gesunden, adulten Pferden keine klinischen Zeichen einer Hypersulfatämie hervor. Daher können diese Formulierungen dem Kliniker zur Behandlung primärer Obstipationen des Kolons oder Zäkums von Pferden empfohlen werden.

\section{Tierschutzerklärung}

Die Versuche wurden von der zuständigen Tierschutzbehörde genehmigt (AZ 24-9168.21 A 8/06). 